ZOOLOGIA 30 (4): 447-450, August, 2013

http://dx.doi.org/10.1590/S1984-46702013000400012

\title{
Two new species of Costatrichia (Trichoptera: Hydroptilidae: Leucotrichiinae)
}

\section{Allan Paulo Moreira Santos ${ }^{1,2}$, Daniela Maeda Takiya' ${ }^{1} \&$ Jorge Luiz Nessimian ${ }^{1}$}

\author{
${ }^{1}$ Departamento de Zoologia, Instituto de Biologia, Universidade Federal do Rio de Janeiro. Caixa Postal 68044, \\ 21941-971 Rio de Janeiro, RJ, Brazil. \\ 2 Corresponding author.E-mail: a.santos@ufrj.br
}

\begin{abstract}
Costatrichia Mosely, 1937 is a Neotropical genus included in the subfamily Leucotrichiinae. Previously, this genus included 14 described species, two from Brazil and eight from Costa Rica. Based on recent specimens collected with light traps in the Brazilian Amazon and Costa Rica, we describe two new species: Costatrichia ipixuna sp. nov. from the state of Amazonas, Brazil (C. lodora group) and C. falsa sp. nov. from Puntarenas, Costa Rica (C. simplex group). Costatrichia ipixuna sp. nov. is most similar to C. noite Angrisano, 1995, but can be distinguished by the shallower Ushaped incision on posterior margin of sternum VIII, by the absence of the lateral projection of the same segment bearing very long setae, and by the phallus with a pair of spine-like sclerotized processes apically. Costatrichia falsa $\mathbf{s p .}$ nov. is most similar to C. zopilote Harris \& Holzenthal, 1999, but differs from it by the median pair of spines of segment VIII, directed mesad and curved posteriorly crossing over each other; by the irregular posterior margin of segment VIII, in ventral view; by the segment $\mathrm{X}$ without short lateral paired spines; and by the flange-like apical processes on phallus. In addition, we provide the first record of C. noite Angrisano, 1995 from Brazil (state of Amazonas).
\end{abstract}

KEY WORDS. Amazon Forest; Costa Rica; Costatrichia ipixuna sp. nov.; Costatrichia falsa sp. nov.; microcaddisflies.

Leucotrichiinae was erected by FuINT (1970) to include a distinctive group of exclusively New World microcaddisflies. Marshall (1979) proposed a robust classification in her revision of the Hydroptilidae genera and treated the leucotrichiines as a tribe of Hydroptilinae. The group was treated again as a subfamily, when MaLicky (2001) ranked the Ptilocolepidae, a Hydroptilidae subfamily in MARSHALL's (1979) classification, as a caddisfly family.

In a complicated taxonomic history, several genera were described in Leucotrichiinae; of those, some were later removed and then subsequently reassigned to it (Flint 1970, HolzentHaL \& Harris 1992, Harris \& Holzenthal 1993, 1994, Bowles et al. 1999). Presently, the group comprises 189 species in 17 genera, most of which are poorly defined (FLINT 1992, MarShall 1979) and some probably represent synonyms. Therefore, a rigorous phylogenetic study is needed to reassess the status of each genus of Leucotrichiinae.

Costatrichia Mosely includes 14 species recorded from Mexico, Central, and South America. The genus was revised by HOLZENTHAL \& HARRIS (1999), who described most of the known species. It is divided into three species groups based on the presence of antennal and wing modifications in males and on the male genital structures (Fuint 1970, Holzenthal \& HarRis 1999). Recently, species of the genus were recorded from Bra- zil, with one species occurring in the northern and another in the southeastern regions (SAntos \& Nessimian 2010). Since then, specimens collected in Brazil and Costa Rica revealed two additional new species, and also the first record of Costatrichia noite Angrisano, 1995 from Brazil.

\section{MATERIAL AND METHODS}

Specimens were collected with light traps and preserved in $95 \%$ ethanol. To observe and draw the genital structures, the abdomen was removed and cleared in a solution of heated $10 \% \mathrm{KOH}$. Pencil sketches were made under a compound microscope, equipped with a camera lucida, and then used as templates to trace vector graphics in an Adobe Illustrator (v. 13.0.0, Adobe Systems Inc.) document. The structural terminology follows Marshall (1979) and HolzentHAL \& Harris (1999). The descriptions provided for the new species were made with the DELTA software (DALlwitz et al. 1999). The material examined is deposited in Coleção Entomológica Prof. José Alfredo Pinheiro Dutra, Departamento de Zoologia, Universidade Federal do Rio de Janeiro (DZRJ, Rio de Janeiro), Coleção de Invertebrados, Instituto Nacional de Pesquisas da Amazônia (INPA, Manaus), and Instituto Nacional de Biodiversidad (INBio, Santo Domingo de Heredia). 


\section{TAXONOMY}

\section{Costatrichia ipixuna sp. nov.}

Figs 1-9

Description. Male. Length 3.0-4.0 mm $(\mathrm{n}=2)$. General color, in alcohol, dark brown, with green spots on forewings. Head with brush of scale setae on frontal area; 3 ocelli. Antennae (Fig. 1) 20-articulated; dark brown, 16th, 17th, and 18th articles lighter brown; scape and pedicel simple; flagellomeres I-IV short, very broad, and very compressed. Maxillary palpi 5articulated. Labial palpi 3-articulated. Forewings with a short reflexed costal cell covered with dark brown setae; veins reaching wing margins. Hind wings with fringe of long dark brown setae on anal margin; veins reaching wing margin. Segment VII (Fig. 2) with long ventromesal process. Genitalia. Segment VIII (Figs 2 and 4) shorter dorsally than ventrally; posterior margin, in ventral view, with mesal U-shaped incision, and very long, slender, paired processes, in lateral view, directed about $45^{\circ}$ upward. Segment IX (Fig. 3) mostly within segment VIII, opened ventrally. Inferior appendages (Figs 2 and 4) fused mesally, in ventral view, broad basally, with a V-shaped incision on apical margin. Subgenital plate (Figs 2 and 4) long, exceeding length of inferior appendages, narrowing to rounded apex; in lateral view, slightly downturned. Tergum X (Figs 3 and 4) membranous and rounded. Phallus (Figs 5 and 6) tubular basally, bearing midlength complex, with dorsal window and long basal loop; apex with paired, lateral sclerotized spinelike processes.

Female. Length 3.1-3.8 mm $(\mathrm{n}=4)$. Color as in male. Antennae 19-articulated, simple. Ocelli 3. Reflexed costal cell on forewing absent. Segment VI with short ventromesal process. Segment VII long. Genitalia. Segment VIII (Fig. 7) with sternite subquadrate, with ring of long and stout setae on posterior margin; lateral apodemes extending through segment VII. Segment IX (Fig. 7) mostly membranous, in ventral view, divided into rounded paired lobes; lateral apodemes extending to mid of segment VII. Segment X (Fig. 7) with sternite rounded apically, with pair of lateral papillae. Bursa copulatrix (Figs 8 and 9) with long membranous lobe, connected to vaginal sclerite; vaginal sclerite lyre-like, with short spines on internal margin, a transverse sclerite dorsally, and setal brush anteriorly.

Material examined. Holotype male. BraziL, Amazonas: Ipixuna (Rio Liberdade, Comunidade São Vicente, $07^{\circ} 21^{\prime} 47^{\prime \prime S}$ 7152'07"W, 175 m, light trap), 11-14.V.2011, D.M. Takiya, J.A. Rafael leg. (INPA). Paratypes. BRAzIL, Amazonas: Barcelos (Rio

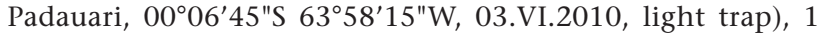
male, 3 females, D.M. Takiya leg. (DZRJ).

Etymology. The species is named after the locality where the holotype was collected. Ipixuna means "black water" in the Tupi-guarani language.

Remarks. This new species belongs to the $C$. lodora Mosely group, due to the modification on the basal articles of the antennae (Fig. 1) and the presence of reflexed costal cell on the forewings. Costatrichia ipixuna sp. nov. is most similar to $C$. noite, because both species have a pair of very long, slender processes on the posterior margin of sternum VIII and fused inferior appendages forming a ventral plate, broad basally and incised apically (Fig. 2). However, the new species has a shallower U-shaped incision on posterior margin of sternum VIII and lacks the lateral projection of the same segment with very long, stout setae, which is present in C. noite. Additionally, the new species differs in the phallus, which bears a pair of spinelike sclerotized processes apically (Fig. 6).

Ecological notes. Sampling in both localities from where type specimens were collected were at borders of terra firme Amazonian forests with white sheet and mixed mercury vapor lamps.

\section{Costatrichia falsa sp. nov. Figs $10-14$}

Description. Male. Length 2.0-2.2 mm $(\mathrm{n}=5)$. General color, in alcohol, dark brown, with green spots on forewings. Head with three ocelli. Antennae dark brown, 18-articulated, simple; pedicel long. Maxillary palpi 5-articulated. Labial palpi 3 -articulated. Forewings without reflexed costal cell; veins reaching wing margins. Hind wings with fringe of long dark brown setae on anal margin; veins reaching wing margin. Segment VII (Fig. 10) with short ventromesal process. Genitalia. Segment VIII (Figs 10 and 12) shorter dorsally than ventrally; posterior margin, in ventral view, with mesal U-shaped incision; lateral lobes with 3 long, thick, paired spines, median pair very long, crossing over each other. Segment IX (Fig. 10) mostly within segment VIII, opened ventrally. Inferior appendages (Figs 10 and 12) short, fused mesally; with two paired, finger-like processes, each bearing apical seta. Subgenital plate absent. Tergum X (Fig. 11) membranous and pentagonal, in dorsal view. Phallus (Figs 13 and 14) tubular basally, bearing midlength complex, with dorsal window and long, thin basal loop; apex with paired, sclerotized flange-like lateral processes. Female unknown.

Material examined. Holotype male. Costa Rica, Puntarenas: La Gamba (Esquinas Lodge, river at waterfall trail, $08^{\circ} 41^{\prime} 05^{\prime \prime} \mathrm{N}$ $83^{\circ} 12^{\prime} 17 " \mathrm{~W}, 70 \mathrm{~m}$, light trap), 21-22.II.2011, D.M. Takiya leg. (INBio). Paratypes. Same data as holotype, 4 males (DZRJ).

Etymology. The name of this species refers to its uncertain position in the genus Costatrichia, from the Spanish "falsa".

Remarks. Costatrichia falsa sp. nov. is similar in the structure of male genitalia to C. zopilote Harris \& Holzenthal, tentatively placed in the C. simplex Flint group. HarRis \& HolzentHaL (1999) mentioned the uncertain position of C. zopilote in this genus because it has features found in another leucotrichiine genus, Acostatrichia Mosely. While a complete reassessment of the genera included in the subfamily is not available, these two species are maintained in Costatrichia, despite the fact that their affinities with the other described species are obscure. This new species, as C. zopilote, has thick and very long spines arising from lateral lobes of segment VIII (Fig. 12) and inferior append- 

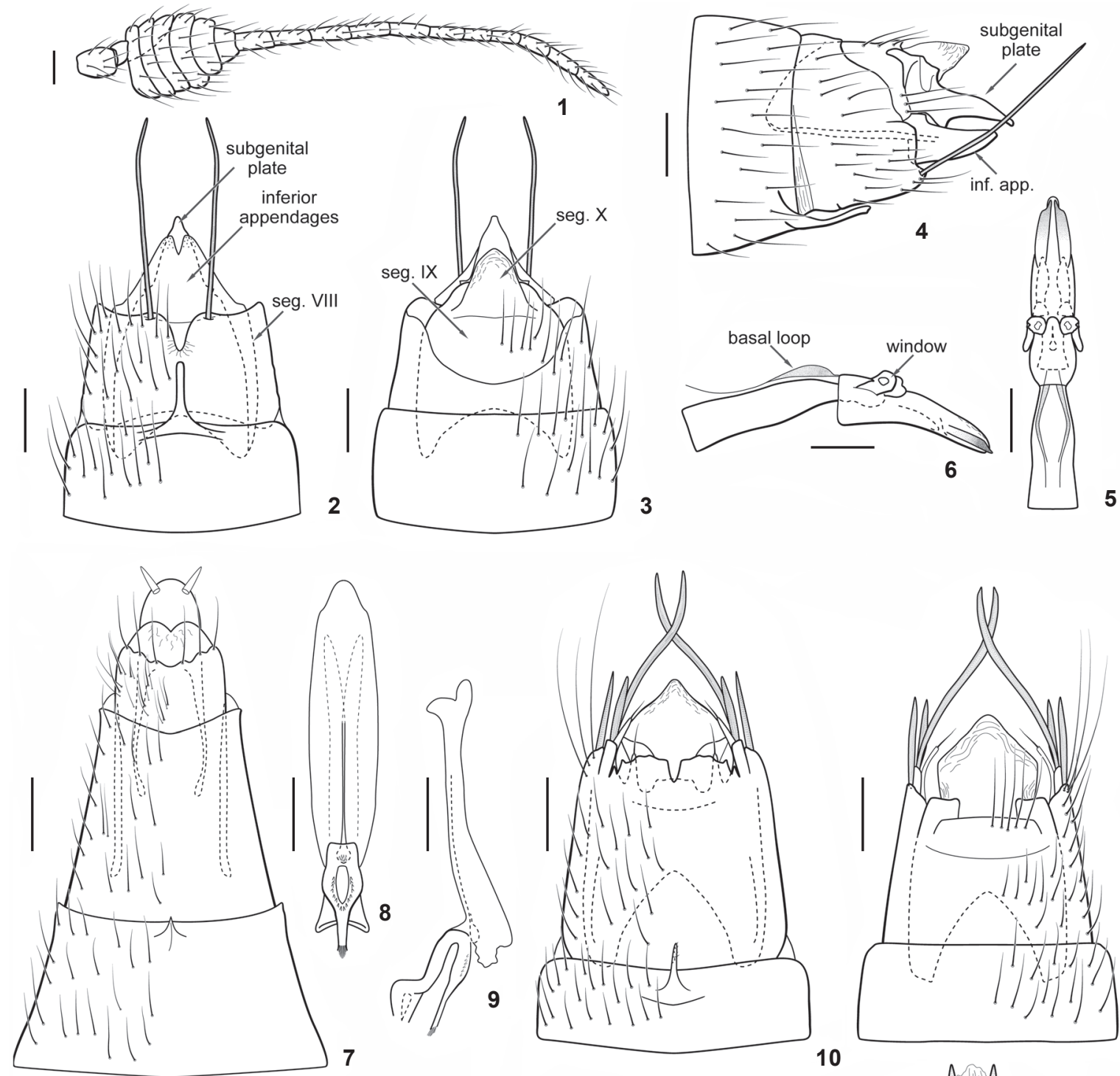

10
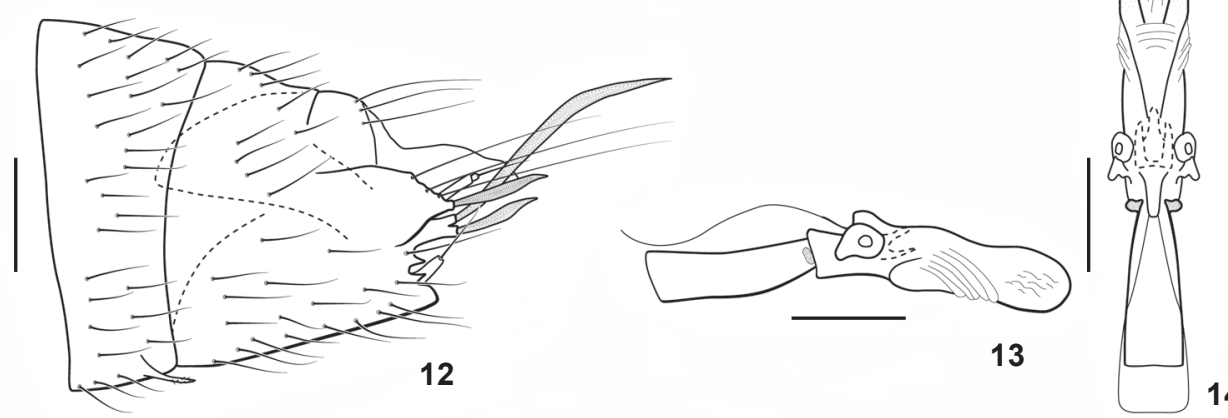

Figures 1-14. (1-9) Costatrichia ipixuna sp. nov. (1-6) Male: (1) antenna, lateral view; (2-6) genitalia: (2) ventral view; (3) dorsal view; (4) lateral view; (5) phallus, dorsal view; (6) phallus, lateral view. (7-9) Female: (7) terminal segments of abdomen, ventral view; (8) bursa copulatrix, ventral view; (9) bursa copulatrix, lateral view. (10-14) Costatrichia falsa sp. nov., male genitalia: (10) ventral view; (11) dorsal view; (12) lateral view; (13) phallus, dorsal view; (14) phallus, lateral view. Scale bar $=0.1 \mathrm{~mm}$. 
ages fused basally with paired finger-like processes (Fig. 10). However, the new species differs from C. zopilote in the following features: 1) median pair of spines of segment VIII, which are directed mesad and curved posteriorly crossing over each other (Fig. 10); 2) irregular posterior margin of segment VIII, in ventral view (Fig. 10); 3) segment $X$ without short lateral paired spines; and 4) flange-like apical processes on phallus.

Ecological notes. Sampling of type specimens were conducted with two UV tubes over a 90\% ethanol-filled plastic tray at the river bed. This river was found within the lodge preserved area of tropical lowland forest.

\section{Costatrichia noite Angrisano, 1995}

Remarks. Angrisano (1995) described this species from one specimen from Uruguay. Holzenthal \& Harris (1999) recorded C. noite from Peru and provided additional illustrations of the male genitalia. This species is herein recorded from Brazil, state of Amazonas, confirming its wider distribution in South America.

Distribution. Brazil (new record), Peru (Holzenthal \& Harris 1999), and Uruguay (ANgrisano 1995).

Material examined. BraziL: Amazonas: Ipixuna (Rio Liberdade, Comunidade Santa Catarina, 07²19'46"S 71 $50^{\prime} 46^{\prime \prime} \mathrm{W}$, 169 m, 10.V.2011, light trap), 1 male, D.M. Takiya leg. (DZRJ). Brazil: Amazonas: Ipixuna (Rio Gregório, Comunidade Lago Grande no Seringal do Recreio, 07010'06"S 70²9'06"W, 145 m, 17-23.V.2011, light trap), 1 male, D.M. Takiya leg. (DZRJ).

\section{ACKNOWLEDGMENTS}

CAPES and CNPq provided fellowships to APMS and JLN, respectively. This research was partially funded by PROTAX (CNPq) and APQ1 (FAPERJ) research grants to JLN. Collection of Brazilian specimens was possible thanks to the project "Amazonas: Diversidade de insetos ao longo de suas fronteiras", headed by José Albertino Rafael (INPA, PRONEX/FAPEAM). Travel to and collection of Costa Rican specimens were facilitated by A.H. Villalobos and T.J. Lewis (INBio) and G. Kunz (Karl Franzens Universität Graz).

\section{LITERATURE CITED}

Angrisano, E.B. 1995. Contribucion al conocimiento de los Trichoptera del Uruguay II, Familia Hydroptilidae. Revista Brasileira de Entomologia 39: 501-516.

Bowles, D.E.; S.C. Harris \& J. Bueno-Soria. 1999. An assessment of New World Stactobiini (Trichoptera: Hydroptilidae: Hydroptilinae) larvae with new larval descriptions of
Alisotrichia, Mejicanotrichia, and Scelobotrichia, p. 43-52. In: H. Malicky \& P. Chantaramongrol (Eds). Proceedings of the 9th International Symposium on Trichoptera. Chiang Mai, Faculty of Science, Chiang Mai University.

Dallwitz, M.J.; T.A. Paine \& E.J. Zurcher. 1999. User's guide to the DELTA Editor. Available online at: http://deltaintkey.com [accessed: 4/V/2012].

Flint JR, O.S. 1970. Studies of Neotropical caddisflies, X: Leucotrichia and related genera from North and Central America (Trichoptera: Hydroptilidae). Smithsonian Contributions to Zoology 60: 1-64.

FLINT JR, O.S. 1992. Studies of Neotropical caddisflies XXXVIII: a review of the classification and biology of the Neotropical microcaddisflies, with the description of a new genus (Trichoptera: Hydroptilidae: Leucotrichiini), p. 525-531. In: D. Quintero \& A. Aiello (Eds). Insects of Panama and Mesoamerica: Selected Studies. Oxford, Oxford University Press.

Harris, S.C. \& R.W. Holzenthal. 1993. Phylogeny of the species groups of Alisotrichia, sensu lato, with the description of a new species from Costa Rica (Trichoptera: Hydroptilidae), p. 155-160. In: C. Отто (Ed.). Proceedings of the 7th International Symposium on Trichoptera. Leiden, Backhuys Publishers.

HaRrIs, S.C. \& R.W. HolzentHal. 1994. Hydroptilidae (Trichoptera) of Costa Rica and Neotropics: systematics of the genus Byrsopteryx Flint (Stactobiini). Journal of the New York Entomological Society 102: 154-192.

Holzenthal, R.W. \& S.C. HaRRIs. 1992. The larva of Byrsopteryx mirifica Flint, with an assessment of the phylogenetic placement of the genus within the Leucotrichiini (Trichoptera: Hydroptilidae), p. 403-407. In: C. TomaszewsKI (Ed.). Proceedings of the 6th International Symposium on Trichoptera. Poznan, Adam Mickiewicz University Press.

Holzenthal, R.W. \& S.C. Harris. 1999. The genus Costatrichia Mosely in Costa Rica, with a review of the Neotropical species (Trichoptera: Hydroptilidae). Proceedings of the Entomological Society of Washington 101: 540-568.

MaLicky, H. 2001. Notes on the taxonomy of Rhadicoleptus, Ptilocolepus and Pseudoneureclipsis. Braueria 28: 19-20.

Marshall, J.E. 1979. A review of the genera of the Hydroptilidae (Trichoptera). Bulletin of the British Museum (Natural History), Entomology Series 39: 135-239.

Santos, A.P.M. \& J.L. Nessimian. 2010. The occurrence of the microcaddisfly genus Costatrichia (Trichoptera: Hydroptilidae: Hydroptilinae) in Brazil with description of two new species. Zoologia 27: 837-843.

Submitted: 01.IV.2012; Accepted: 19.V.2013.

Editorial responsibility: Gabriel L.F. Mejdalani 